\title{
Biodecolourization of Yellow Dye Using Chlorella Vulgaris and Sphaerocystics Schroeteri
}

\author{
Ezenweani Sunday Raymond ${ }^{1}$, Kadiri Medina Omo ${ }^{2}$ \\ ${ }^{1}$ Department of Marine Environment and Pollution Control, Faculty of Maritime Environmental Management, Nigeria Maritime University, \\ Warri, Nigeria \\ ${ }^{2}$ Department of Plant Biology and Biotechnology, Faculty of Life Science, University of Benin, Benin City, Nigeria
}

\section{Email address:}

raysunny65@yahoo.com (E. S. Raymond)

\section{To cite this article:}

Ezenweani Sunday Raymond, Kadiri Medina Omo. Biodecolourization of Yellow Dye Using Chlorella Vulgaris and Sphaerocystics Schroeteri. American Journal of Biological and Environmental Statistics. Vol. 5, No. 1, 2019, pp. 1-6. doi: 10.11648/j.ajbes.20190501.11

Received: December 14, 2018; Accepted: January 2, 2019; Published: January 31, 2019

\begin{abstract}
The application of biodecolourization of textile effluents is a cost effective, environmental friendly and appropriate alternative measure in the treatment of textile effluents. In this study, two microalgae namely; Chlorella vulgaris and Sphaerocystis schroeteri were used. Yellow coloured dye was used for this study and dye solution were prepared in different concentrations of $1 \mathrm{mg} / 1,5 \mathrm{mg} / 1,10 \mathrm{mg} / 1$ and $20 \mathrm{mg} / 1$. Significant decolourization was recorded in a 14 day experiment carried out by reading the absorbance of the dye solution inoculated with microalgae. Maximum decolourization by both algae was obtained at $10 \mathrm{mg} / \mathrm{l}$. In Chlorella vulgaris, maximum decolourization was $43.12 \%$ (10mg/l) while in Sphaerocystis schroeteri, maximum decolourization was $45.03 \%(10 \mathrm{mg} / 1)$. The order of highest percentage decolourization for Chlorella vulgaris was $10 \mathrm{mg} / 1,20 \mathrm{mg} / 1,5 \mathrm{mg} / 1,1 \mathrm{mg} / 1$, while in Sphaerocystis schroeteri, the order was $10 \mathrm{mg} / 1,5 \mathrm{mg} / 1,20 \mathrm{mg} / 1,1 \mathrm{mg} / 1$. During the study, maximum dye decolourization, irrespective of the concentration and algae was obtained on the final day. In Chlorella vulgaris, the minimum and maximum decolourizations respectively, were $19.42 \%$ and $43.12 \%$, but in Sphaerocystis schroeteri, the minimum and maximum decolourization respectively, were $24.27 \%$ and $45.03 \%$. However, decolourization was significantly dependent on dye concentration. Comparatively, there was no significant difference between the percentage decolourization by the two microalgae.
\end{abstract}

Keywords: Biodecolourization, Algae, Textile, Dye, Absorption, Effluent

\section{Introduction}

Dye is a coloured, ionizing and aromatic organic compound. It is generally applied in aqueous solution and shows affinity towards the substrate to which it is applied, $[5]$.

The world's ever progressive adoption of an industrial based life style has undoubtedly led to an increased anthropogenic impact on the environment. These industries have shown a significant increase in the use of synthetic organic dyes as the coloring materials. The global consumption of textile products is currently around 30 million tones with expected growth at $3 \%$ per annum, and the colouration of this total needs approximately 800,000 tons of dye. It is estimated that 10,000 different types of dyes and pigments are produced worldwide annually [23]. A large number of dyes are Azo compounds $(-\mathrm{N}=\mathrm{N}-)$, which are linked by an Azo bridge and are used by a wide range of industries. Dyes usually have a synthetic origin and complex aromatic molecular structures, which possibly come from coal-tar based hydrocarbons such as benzene, naphthalene, anthracene, toluene and xylene [2]. Although textile mills use them predominantly, dyes can also be found in the food, paper and printing, leather, pharmaceutical, and cosmetic industries [4]. Synthetic textile dyes used each year are lost during manufacture and processing operation, and $20 \%$ of these dyes enter the aquatic environment through effluents that result from the treatment of residual industrial waters [4].

Biological techniques which are cheaper and easier to operate have become the focus in recent studies of dye degradation and decolourization. Microbial, algal, fungal and enzymatic decolorization and degradation of textile dyes have significant potential to address this problem due to their environmentally-friendly and inexpensive nature, and they do 
not produce large quantities of sludge [21] Micro algae are known to remove dyes by bioabsorption, biodegradation, bioconversion, biovolatilization and biotransformation. Microalgae degrade dyes of nitrogen source by removing nitrogen, phosphorus, and carbon from water, it can help reduce eutrophication in the aquatic environment $[18,19]$, and are unique in sequestering carbon dioxide, one of the main contributors to the greenhouse effect [14]. Moreover, microalgae can grow at a rapid pace, and in inhospitable conditions, using water unfit for human consumption [14].

Several other physical and chemical methods have been suggested for the treatment of dye-contaminated wastewater such as flocculation with lime, charcoal, bark, rice husk, coal, pea-nut shell, clay, cotton waste, biogas slurry waste banana pith. There are several ways by which plants clean up or remediate contaminated sites and there are phytoextraction, rhizofiltration, phytotransformation, phytostabilization and phytovolatilization [16]. The application of various aquatic species like Phragmites australis, Typhonium flagelliform, Eichhornia crapssipes, Azolla caroliniana, Typha, lemna and microalgae etc. to remediate and decolourize dye and other pollutants from waste water has gained increasing interest in recent times [6].

This work addresses the ability of microalgae; Chorella vulgaris and sphaerocystisschroeteri as efficient phytodecolourizer and bioaccumalator to decolourize textile dye solution. Removing colour from wastes is imperative, because the presence of even small amounts of dyes (below 1 ppm) is clearly visible and influences water environment considerably.

\section{Materials and Method}

\subsection{Experimental Setup}

Completely Randomized Block Design which involves 2 microalgae, a dye colours, 4 treatments and 3 replicates was used in this study to demonstrate the ability of microalgae in dye decolourization. Two algal species were used in this study and they include; Chlorella vulgaris and Sphaerocystics schroeteri. The collection was made few hours prior to experimental setup. Cell counting was done using light microscope to determine the concentration of the algal biomass. Yellow textile dye was used in this experiment and was prepared in different concentrations; $1 \mathrm{mg} / 1,5 \mathrm{mg} / 1$, $10 \mathrm{mg} / \mathrm{l}$, and $20 \mathrm{mg} / 1$.

Prior to the experimental setup, the bottles were acid washed and the desk was cleaned with ethanol. The ratio of the volume of Chlorella vulgaris and Sphaerocystis schroeteri cells were determined to be $4: 1$ respectively after they were viewed. Therefore, in order to unify the inoculation, $6.25 \mathrm{ml}$ of sphaerocystis schroeteri was used to inoculate each replicate of each treatment of each dye solution and $25 \mathrm{ml}$ of Chlorella vulgaris was also used in the inoculation in the same manner. Inoculation was done with brand new syringe to eliminate contamination and to ensure accuracy in measurement, and bottle was immediately caped with cotton wool after inoculation. Each experimental bottle contained 300mlof dye solution and algal biomass and were arranged systematically in replicates and placed outside the laboratory where they were faced with natural environment.

\subsection{Determination of Percentage Decolourization}

The decolourization progress was read using Search Tech $721 \mathrm{GVisible}$ spectrophotometer by reading absorbance at maximum wavelength for the dye. The maximum wavelength of the dye was determined to be $446 \mathrm{~Hz}$, and control (blank) was $380 \mathrm{~Hz}$. Reading was taken from the day the experiment was setup as the initial (Day0). Thereafter, the reading was taking for Day 2, Day 4, Day 6, Day 8, Day 10, Day 12 and Day 14. Percentage decolourization was determined using the formula according to [10].

Initial abs - final abs $\times 100$

Initial abs

Reading was done by taking $5 \mathrm{ml}$ of each sample, filtering and reading absorbance. Filtering was to avoid algal cells from contributing to the reading. There was systematic randomization with the way the bottles were being arranged outside each day after reading. The replicate bottles were exchanged every two days to ensure equal exposure to environmental factors.

\subsection{Chlorophyll Determination}

This was measured at the end of the experiment. The method of Talling (1974) was used. This was read using Hach DR 2000 spectrophotometer after the final day. $50 \mathrm{ml}$ of each sample was taken and filtered through GCF filter paper. Chlorophyll was extracted using $90 \%$ acetone and sample was kept for 24 hours before reading at the wavelength 665,645 , and $630 \mathrm{~Hz}$. This method is known as trichomatic method and it distinguishes contribution from pigments with overlapping spectra e.g. Chlorophyll a, b and c.

Chlorophyll $\mathrm{a}$ b and $\mathrm{c}$ were calculated using the formula below [22].

$\mathrm{Ca}=11.6 \mathrm{D}(\mathrm{abs}=665)-1.31 \mathrm{D}(\mathrm{abs}=645)-0.14 \mathrm{D}$ $(\mathrm{abs}=630)$

$\mathrm{Cb}=20.7 \mathrm{D}(\mathrm{abs}=665)-4.34 \mathrm{D}(\mathrm{abs}=645)-4.42 \mathrm{D}$ $(\mathrm{abs}=630)$

$\mathrm{Cc}=55.0 \mathrm{D}(\mathrm{abs}=630)-4.64 \mathrm{D}(\mathrm{abs}=665)-16.3 \mathrm{D}$ $(\mathrm{abs}=645)$

$\mathrm{Chla}=\mathrm{Ca} \times \mathrm{v}, \mathrm{Chlb}=\mathrm{Cb} \times \mathrm{v}, \mathrm{Chlc}=\mathrm{Cc} \times \mathrm{v}$,

$\mathrm{V} \times \mathrm{I} \mathrm{V} \times \mathrm{I} \mathrm{V} \times \mathrm{I}$

Where $\mathrm{V}=$ Volume of sample filtered for extraction, $\mathrm{v}=$ volume of acetone, $\mathrm{I}=$ Path length of cuvette.

\subsection{Statistical Analysis}

ANOVA was used to determine the significance of change in concentration in the dye decolourization. Unpaired $\mathrm{T}$ test was used to determine if there is significant difference in the extent of dye decolourization between the two algae in all concentration. Unpaired $\mathrm{T}$ test was used to determine if there is significant different in the growth of the two algae in the 
control sample. PAST Statistical software was used.

\section{Results}

This study determined if the use of microalgae in decolourization of textile dye is effective, and shows the level of significance to which it is effective. The result of this study is hence presented as follows.

Figure 1 shows the percentage decolourization of dye by
Chorella vulgaris. The maximum percentage decolourization was found in $10 \mathrm{mg} / 1$ which read $43.13 \%$ while the minimum percentage decorlourization was recorded in $1 \mathrm{mg} / 1$ which read $19.42 \%$. The mean final decolourization was 33.17 \pm 5.10 . ANOVA analysis showed that the effect of change in dye concentration was significant in dye decolourization at $10 \mathrm{mg} / \mathrm{l}$ concentration. There was no significant difference between $5 \mathrm{mg} / 1$ and $20 \mathrm{mg} / 1$.

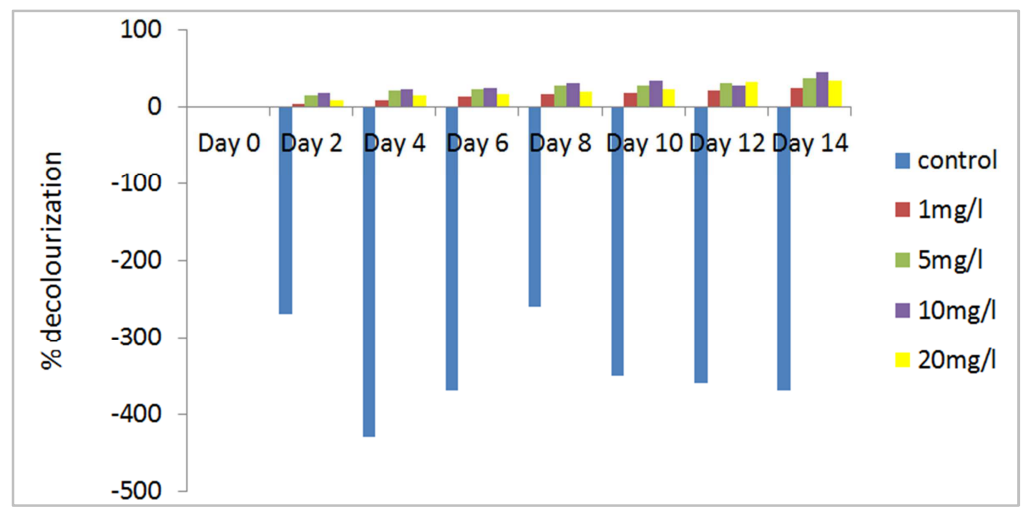

Figure 1. Percentage dye decolourization by Chlorella vulgaris.

Figure 2 shows the percentage decolourization dye by Sphaerocystis schroeteri. The maximum percentage decolourization was found in $10 \mathrm{mg} / 1$ with $45.03 \%$ while the minimum percentage decorlourization was recorded in $1 \mathrm{mg} / 1$ which read $24.27 \%$. The mean final decolourization was
$34.93 \pm 4.29$. ANOVA analysis showed that the effect of change in dye concentration was significant in dye decolourization at $10 \mathrm{mg} / \mathrm{l}$ concentration. There was no significant difference between $5 \mathrm{mg} / 1$ and $20 \mathrm{mg} / 1$.

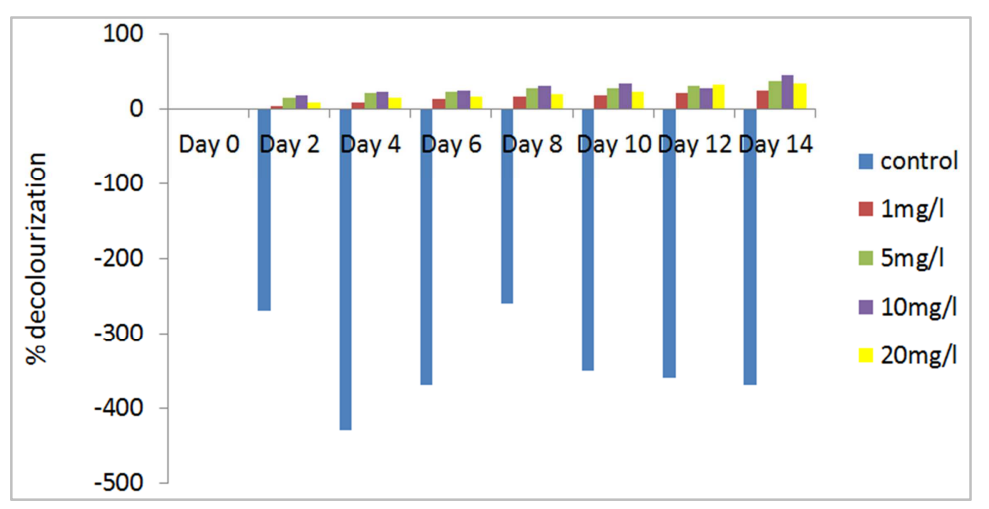

Figure 2. Percentage yellow dye decolourization by Sphaerocystis schroeteri.

In control experiment using Chlorella vulgaris, there was significant increase in absorbance reading with day 14 increasing by $650 \%$, day 2 by $412.40 \%$ which was the minimum and the maximum increase was recorded in day 6 which increased by $700 \%$.
In control using Sphaerocystis schroeteri, the increase in absorbance reading in day 14 was $370 \%$, in day 2 was $270 \%$ which was the minimum and the maximum increase was recorded in day 4 where the recorded increase was $429.90 \%$.

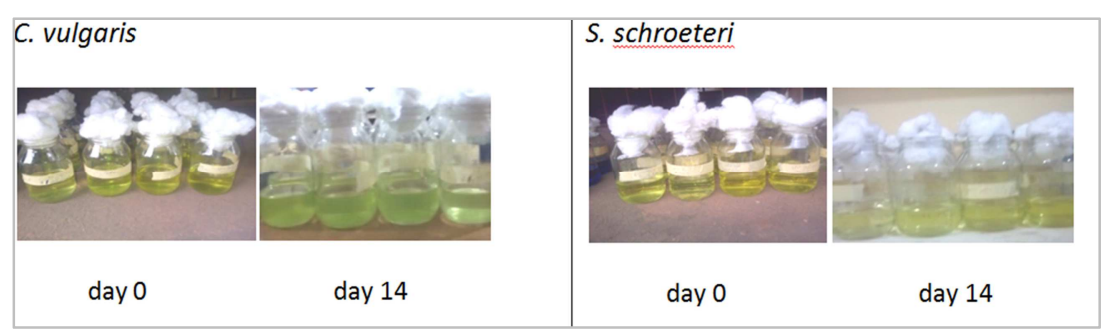

Figure 3. Physical examination of day 0 and day 14 replicates of $C$. vulgaris and S. schroeteri. 


\subsection{Comparative Assessment of Dye decolourization by the Two Microalgae}

In comparing the effectiveness of using the two microalgae in dye decolourization, unpaired $\mathrm{T}$ text showed that there was no significant difference in the percentage decolourization attained by the two algae.

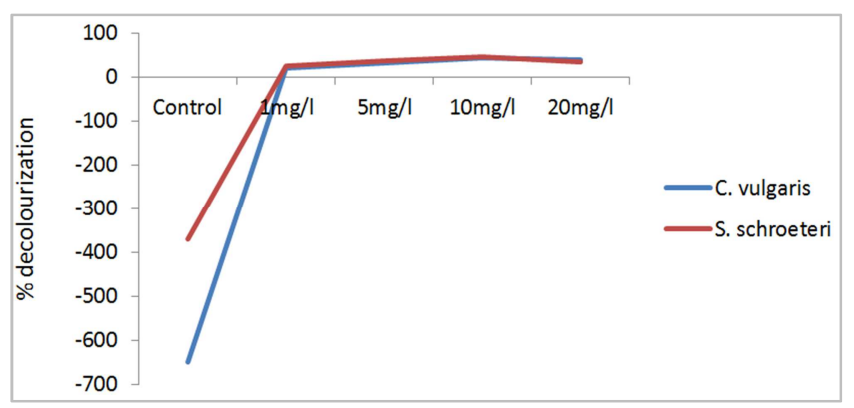

Figure 4. Comparative analysis of dye decolourization by the two algae in dye at the end of the experiment.

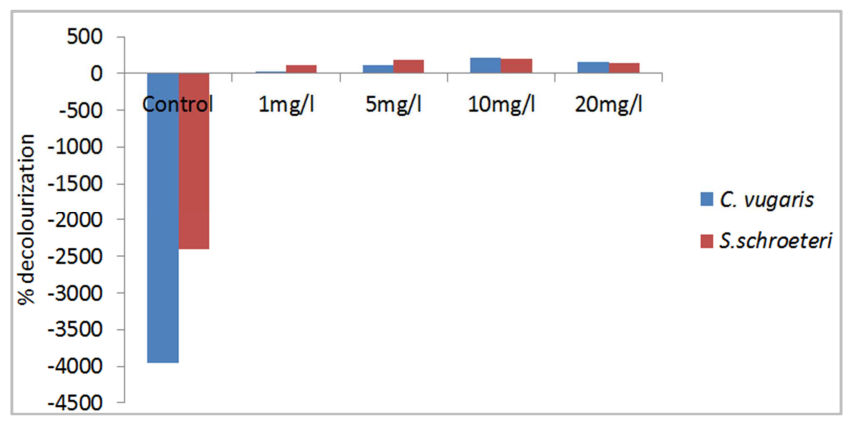

Figure 5. Cumulative percentage decolorization by the two microalgae in dye.

Table 1. Percentage decolourization of dye at the end of the experiment.

\begin{tabular}{lll}
\hline Conc. $\mathbf{M g} / \mathbf{l}$ & Chlorella vulgaris & Sphaerocystis schroeteri \\
\hline 1 & 19.42 & 24.27 \\
5 & 32.20 & 36.86 \\
10 & 43.12 & 45.03 \\
20 & 37.95 & 33.56 \\
Control & -650 & -370 \\
\hline
\end{tabular}

Table 2. Cumulative percentage decolourization in concentrations (entire period of the experiment).

\begin{tabular}{lll}
\hline Conc. (mg/l) & Chlorella vulgaris & Sphaerocystis schroeteri \\
\hline 1 & 29.12 & 105.82 \\
5 & 113.56 & 180.04 \\
10 & 207.81 & 202.57 \\
20 & 153.66 & 145.42 \\
Control & -3949.9 & -2409.9 \\
\hline
\end{tabular}

\subsection{Chlorophyll Concentration at Termination Day of Experiment}

Table 3 and 4 show the chlorophyll (Chlorophyll a, b and c) concentration of the two algae (Chlorella vulgaris and Sphearocystis schroeteri) in dye at the end of the experiment respectively.
Table 3. Chlorophyll concentration of Chlorella vulgaris in dye.

\begin{tabular}{llll}
\hline Dye Conc. & $\begin{array}{l}\text { Chlorophyll a } \\
(\boldsymbol{\mu m} / \mathbf{l})\end{array}$ & $\begin{array}{l}\text { Chlorophyll b } \\
(\boldsymbol{\mu m} / \mathbf{l})\end{array}$ & $\begin{array}{l}\text { Chlorophyll c } \\
(\boldsymbol{\mu m} / \mathbf{l})\end{array}$ \\
\hline 1 & 2.383 & 3.773 & 0.277 \\
5 & 2.396 & 3.752 & 0.364 \\
10 & 2.580 & 4.028 & 0.613 \\
20 & 2.227 & 3.511 & 0.407 \\
Control & 2.692 & 4.174 & 0.911 \\
\hline
\end{tabular}

Table 4. Chlorophyll concentration of Sphaerocystis schroeteri in dye.

\begin{tabular}{llll}
\hline Dye Conc. & $\begin{array}{l}\text { Chlorophyll a } \\
(\boldsymbol{\mu m} / \mathbf{l})\end{array}$ & $\begin{array}{l}\text { Chlorophyll b } \\
(\boldsymbol{\mu m} / \mathbf{l})\end{array}$ & $\begin{array}{l}\text { Chlorophyll c } \\
(\boldsymbol{\mu m} / \mathbf{l})\end{array}$ \\
\hline 1 & 1.862 & 2.927 & -0.001 \\
5 & 1.697 & 2.692 & -0.265 \\
10 & 1.781 & 2.791 & -0.245 \\
20 & 1.615 & 2.744 & -0429 \\
Control & 1.968 & 3.097 & -0.223 \\
\hline
\end{tabular}

\section{Discussion}

This study demonstrates the effectiveness of using microalgae in the decolourization of textile dyes. In earlier time, scientists have employed the technology of using microorganisms in degrading and accumulating textile dye solutions and effluents, and it has now been also proven by many researchers that algae can properly be employed to degrade and accumulate these textile dye solution or effluents.

[9] suggested that the dye removal may be attributed to the accumulation of dye ions on the surface of algal biopolymers and further to the diffusion of the dye molecule from aqueous phase onto solid phase of the biopolymer. There are other means of colour removal such as assimilative utilization of chromophores for the production of molecules to noncoloured molecules and adsorption of chromophores on algal biomass, biosorption followed by bioconversion and biocoagulation [15].

In yellow dye, it was noticed that the highest decolourization was in $10 \mathrm{mg} / \mathrm{l}$ been higher that $1 \mathrm{mg} / \mathrm{l}$. This is similar to result reported by [8] in the bioremediation of textile waste effluent by Chlorella vulgaris where they reported that highest colour and COD removal occurred in $17.5 \%$ textile waste effluent and was lesser in $5.0 \%$ textile waste effluent. In [3], using Chlorella vulgaris to remove malachite green, it was recorded that $100 \%$ removal was attained in concentrations $(0.01,0.05$ and $0.1 \mathrm{mg} / \mathrm{l})$ in 10 days by using batch culture experiment. In this experiment, with concentrations $(1 \mathrm{mg} / 1,5 \mathrm{mg} / 1,10 \mathrm{mg} / 1,20 \mathrm{mg} / \mathrm{l})$, the highest decolourization using both Chlorella vulgaris and Sphaerocystis schroeteri was $45 \%$ in $10 \mathrm{mg} / \mathrm{l}$. The lower percentage decolourization in this work may be as a result of higher dye concentrations used, difference in algal biomass, climate difference and other environmental conditions.

Looking at figure 2 and 6 , there was a characteristic resemblance in trend observed in the decolourization patterns of both organisms used. In duration, when comparing this work with the experiment carried out by 10 in the 
decolourization of textile dye effluent using Lyngba sp, it is noticed that their work took a duration of 15 days to attain $73 \%$ decolourization while it took Sphaerocystis schroeteri 14 days to attain above $45 \%$ decolourization.

In comparism with the work done by [6] in the indigo blue dye decolourization potential of immobilized Scenesdesmus quadricauda, they reported that the rate of dye decolorization had a linear relationship with increase in concentration of the dye in solution as increasing dye concentration in the medium significantly reduced the rate of decolourization. In this experiment, ANOVA analysis to show the effect of change in concentration on percentage decolourization showed that change in concentration significantly changed the percentage decolourization, but the effect was not a linear relationship with increase in dye concentration as reported by [6]. But this result supports the result reported by [8] in the bioremediation of the textile waste effluent by Chlorella vulgaris where they reported that highest colour and COD removal occurred in $17.5 \%$ textile waste effluent and was lesser in $5.0 \%$ textile waste effluent. [1] reported in the decolorization of malachite green and methylene blue by Chlorella vugaria and Dunaliella salina that the rate of decolourization was found to increase with the increase in algal concentration.

Unpaired $\mathrm{T}$ test analysis showed that there was no significant difference in the percentage decolourization attained by the two algae used in this assessment at the end of the experiment. Algal growth and consequent blooming resulted to increase in spectrophotometric reading as observed in the control experiment where the day 14 was significantly higher than day 0 . As seen from figure 1 to 2 , the negativity in control bar is as a result of algal growth. Unpaired $\mathrm{T}$ test analysis showed that there is a significant difference in the growth rate and extent of the two algae used. It was observed that Chlorella vulgaris had significantly higher growth than Sphaerocystis schroeterias shown by the control bar in figure 1 to 2 . This means that Chorella vulgaris grew faster than Sphaerocystis schroeteri.

From the chlorophyll reading represented in table 3 to 4 , when comparing the chlorophyll content or concentration of algae in dye samples with the control samples at the end of the experiment, the chlorophyll concentration was found to be higher in the control samples than in the dye samples for both Chlorella vulgaris and Sphaerocystis schroeteri. The higher chlorophyll content of algae contained in the control samples is an estimation and identification of the toxic effect of the dye on the algae.

In this experiment, toxicity of the dye solution did not have a linear relationship with increase in dye concentration this corroborates the result reported by [8] in the bioremediation of the textile waste effluent by Chlorella vulgaris where they reported that highest colour and COD removal occurred with $17.5 \%$ textile waste effluent and was lesser with $5.0 \%$ textile waste effluent.

From this experiment, it is evident that the application of dye effluents in the culture of algae while achieving ecofriendly and sustainable decolourization is obtainable.

\section{Conclusion}

Textile effluents can be treated using biological methods before discharge into water bodies. It is seen that Chlorella vulgaris and Sphaerocystis schroeteri can decolourized colured effluents but this generally depends on factors such as concentration, algal biomass and the state of algal used in inoculation. Thus the use of algae as sorbent for the treatment of coloured waste water will provide alternative measure to the conventional treatment method. However, use of algae to remove colour from textile waste water is still in research. Effort is needed for the selection of suitable algae and commercialization of this technology based on economic and market analysis, therefore, continuous assessment of suitable algae for this purpose is recommended. In using this current method for effluents' colour removal before discharge into the water bodies, there can be achievement of environmental friendly and sustainable management.

\section{References}

[1] Abd-El-Kareem, M. S., and Taha, H. M. 2012. Decolorization of malachite green and mythylene blue by microalgal species. International Journal of Chemical and Environmental Engineering (3), pp 397-302.

[2] Ali, M. D., Suresh, A., Kumar, P. R., Gunasekarem, M. and Thajuddin N. 2011. Efficiency of textile dye decolourization by marine cyanobacterium, Oscillatoriaformosa NTDMO2. African Journal of Basic Science (3) pp 9-13.

[3] Al-Taee M. M. S and Al-Ahmed S. G. K. 2012. Biological decolourization of malachaite green dye from aqueous solution by algae. Journal of Pure and Applied Science, 20: 2-11.

[4] Asamudo, R. R., Daba, A. S. and Ezeronyel, O. U. 2005. Bioremediation of textile effluent using Phanerochaete chrysosporium. African Biotechnology (4)pp 1548-1553.

[5] Balter, M. (2009). Clothes make the (hu) man. Science (325)pp 1329-1337

[6] Chai, M. A., Odoh, A. O. and Zakari, L. 2014. The indigo blue dye decourization potential of immobilized Scenedesmus quadricauda. Interenational Journal of Environmental Pollution (225) pp 1-9

[7] Carvalho, K. M. and Martin, D. F. 2011. Removal of aqueous selenium by four aquatic plants. Journal of Aquatic Plant Management (39) pp 33-36.

[8] El-Kasaaas, H. Y. and Mohamed, L. A. 2014. Bioremediation of the textile waste effluent by Chorella vugaris. Egyptian Journal of Aquatic Research (40) pp 301-308.

[9] Gupta, V. K., Rastogi, A., Saini, V. K., Jain, N., 2006. Biosorption of copper (II) from aqueous solutions by Spirogyra species. Journal of Colloid Interface Science (296)pp 59-63.

[10] Gnanadoss, J. J and Jebapriya, G. R. 2013. Decolourization of synthetic dyes using free and immobilized Aspergillus $s p$. Research and Biotechnology (4)pp 20-23.

[11] Henciya, S., Murali, A. and Malliga P. 2013. Decolourization of textile dye effluent by marine cyanobacterium. International Journal of Environmental Sciences (3)pp 1909-1918. 
[12] International Conference on Algal Biomass, 2009. Resources and utilization (ICABRU 09) July, $27^{\text {th }}-30^{\text {th }} 2009$. pp 8.

[13] Integrated Pollution Prevention and Control (IPPC), 2003. Reference document on best available techniques for the textile industry.

[14] Mata, T. M., Martins, A. A. Sikdar, S. and Costa, C. A. V. 2011 Sustainability considerations of biodiesel based on supply chain analysis, clean technology. Environmental Policy (13) pp 655671

[15] Mohan, S. V., Roa, C. N., Prasad, K. K. and Karthikeyan, J. 2002. Treatment of simulated reactive yellow 22 (Azo) dye effluents using Spirogyra species. Waste Management (22)pp $575-582$.

[16] Meers P. , Neville M., Malinin V. A., Scotto W., Sardaryan G., Kurumunda R., Mackinson C., James G., Fisher S. W. and Perkins R. 2008. Biofilm penetration, triggered release and in vivoactivity of inhaled liposomal amikacin in chronic Pseudomonas aeruginosa lung infections. Journal of Antimicrobial Chemotherapy 61 (4): 859-868.

[17] Nawar, S. S. and Doma, H. S. 1989. Removal of dyes from effluents using low cost agricaultural by product. Science Total Environment (79) pp271-179.
[18] Olguin, E. J. (2003). Phycoremediation: Key issue for costeffective nutrient removal process. Biotechnology Advance (22) pp 1-19.

[19] Ozer, A., Akkaya, G., Turabik, M., 2006. The removal of Acid Red 274 from wastewater: combined biosorption and biocoagulation with Spirogyra rhizopus. Dyes Pigment (71)pp 83-89

[20] Ruiz A., Xu X. and Carlson M. 2011 Roles of two protein phosphatases, Reg1-Glc7 and Sit4, and glycogen synthesis in regulation of SNF1 protein kinase. Proc Natl Acad Sci U S A 108 (16): 6349-54

[21] Saratale, R. G., Saratale, G. D, Chang, J. S and Govindwar, S. P. 2011. Bacterial decolourization and degradation of azo dyes: A review. Journal of Taiwan Institute of Chemical Engineering (42)pp 138-157.

[22] Strickland, J. D. H., \& Parsons, T. R., 1965. A manual of sea water analysis. Bull. Fisheries Res. Board Can. no. 125, 2nd Ed., $203 \mathrm{p}$.

[23] Walker, G. M. and Weatherly, L. R. 1997. Absorption of acid dyes onto granular activated carbon in fixed beds. Journal of Water Resources (31)pp 2093-2101. 